Proceedings

\title{
Stereoselective Hydrostannation of Diacrylate and Dimethacrylate Esters of Galactaric Acid Derivatives: Cyclohydrostannation vs. Diaddition ${ }^{\dagger}$
}

\author{
V. Fabricio Terraza ${ }^{1,2}$, Darío C. Gerbino ${ }^{1,3}$ and Julio C. Podestá ${ }^{1, *}$ \\ 1 Instituto de Química del Sur INQUISUR, Departamento de Química, Universidad Nacional del Sur \\ (UNS)-CONICET, Avenida Alem 1253, 8000 Bahía Blanca, Argentina; fabricioterraza87@hotmail.com \\ (V.F.T.); dgerbino@uns.edu.ar (D.C.G.) \\ 2 CIC-PBA, 1900 La Plata, Argentina \\ 3 CONICET, C1425 FQB Ciudad de Buenos Aires, Argentina \\ * Correspondence: jpodesta@uns.edu.ar \\ + Presented at the 22nd International Electronic Conference on Synthetic Organic Chemistry, 15 \\ November-15 December 2018; Available Online: https://sciforum.net/conference/ecsoc-22. \\ Published: 14 November 2018
}

\begin{abstract}
This paper reports a study on the free radical hydrostannation of $\left(\left(4 S, 4^{\prime} R, 5 R, 5^{\prime} S\right)-2,2,2^{\prime}, 2^{\prime}\right.$-tetramethyl-[4,4'-bi(1,3-dioxolane)]-5,5'-diyl)bis(diphenyl methylene) diacrylate (1) and dimethacrylate (2) with triorganotin hydrides, $\mathrm{R}_{3} \mathrm{SnH}(\mathrm{R}=\mathrm{Me}, n-\mathrm{Bu}, \mathrm{Ph})$. Preliminary investigations show that these reactions could lead to mixtures of products of cyclohydrostannation and/or mono- or diaddition according to the organotin hydrides employed and the reaction conditions used. The addition of $\mathrm{Me} 3 \mathrm{SnH}$ to 1 afforded a mixture of three organotin compounds from which the pure new 13-membered macrodiolide $3(48 \%)$ was obtained. The other two organotins could not be separated. The addition of $n$ - $\mathrm{Bu} 3 \mathrm{SnH}$ to diester $\mathbf{1}$ led to a mixture of two organotins, the one in major proportion (91\%) being the product of diaddition 7 . The minor product $6 \mathrm{a}(9 \%)$ could not be isolated pure. The hydrostannation of $\mathbf{1}$ with $\mathrm{Ph} 3 \mathrm{SnH}$ led to one organotin: The product of diaddition 8 . The hydrostannation of the dimethacrylate 2 with the organotin hydrides $\mathrm{R}_{3} \mathrm{SnH}(\mathrm{R}=\mathrm{Me}, n-\mathrm{Bu}, \mathrm{Ph})$ under the same reaction conditions, led in the three cases to mixtures containing mainly diaddition products, and no cyclization products were detected. Some physical characteristics of the new compounds including selected values of ${ }^{1} \mathrm{H},{ }^{13} \mathrm{C}$, and ${ }^{119}$ Sn NMRs are included.
\end{abstract}

Keywords: hydrostannation; cyclohydrostannation; unsaturated diesters of galactaric acid derivatives

\section{Introduction}

We have already reported a new method that enables the synthesis of 11-membered macrodiolides starting from TADDOL unsaturated diesters via a tandem cyclohydrostannation reaction using triorganotin hydrides and diorganotin chlorohydrides. The new macrocycles were obtained in high global yields and with very good diastereoselectivity [1,2]. We also studied the effect of changing the number and the steric volume of the substituents on the structure of the reaction products, i.e., macrocycles and/or diaddition products [3]. In order to determine the effect of the length of the starting unsaturated diesters on the nature of the products, we considered it of interest to study the addition of organotin hydrides to unsaturated diesters derived from D-(+)-galactose. Now, the preliminary results of these investigations are described. 


\section{Results and Discussion}

Taking into account our previous results, the addition under free radical conditions of triorganotin hydrides

$\left(\mathrm{R}_{3} \mathrm{SnH}\right)$

to ((4S,4'R,5R,5'S)-2,2,2',2'-tetramethyl-[4,4'-bi(1,3-dioxolane)]-5,5'-diyl)bis(diphenyl methylene) diacrylate (1) and dimethacrylate (2) could lead to products of cyclohydrostannation (I) and/or diaddition (II), as shown in Scheme 1.

The hydrostannation of unsaturated diesters 1 and $\mathbf{2}$ with organotin hydrides $\mathrm{R}_{3} \mathrm{SnH}(\mathrm{R}=\mathrm{Me}$, $n$-Bu, Ph), was carried out under argon, at $75{ }^{\circ} \mathrm{C}$, with stirring, in toluene and, in one case, without solvent, using azo-bis-isobutyronitrile (AIBN) or UV radiation as radical initiators. The reactions were followed by IR (observing the disappearance of the $\mathrm{Sn}-\mathrm{H}$ absorption) and ${ }^{1} \mathrm{H}$ NMR spectroscopy (observing olefin disappearance and product formation). In all cases, the optimum times of reactions and hydride/olefin ratios required for a quantitative yield (with respect to olefin) were determined.

The addition of $\mathrm{Me} 3 \mathrm{SnH}$ in THF to diester $\mathbf{1}$, at $75^{\circ} \mathrm{C}$, using a ratio tin hydride $\mathbf{1}=2.1$ led, after $12 \mathrm{~h}$ of reaction, to a mixture of three organotin compounds as shown by the ${ }^{119} \mathrm{Sn}$ NMR spectroscopic analysis. Due to the fact that with this substrate the cyclohydrostannation should lead to the creation of one new stereogenic center, a maximum of two diastereomers were expected.
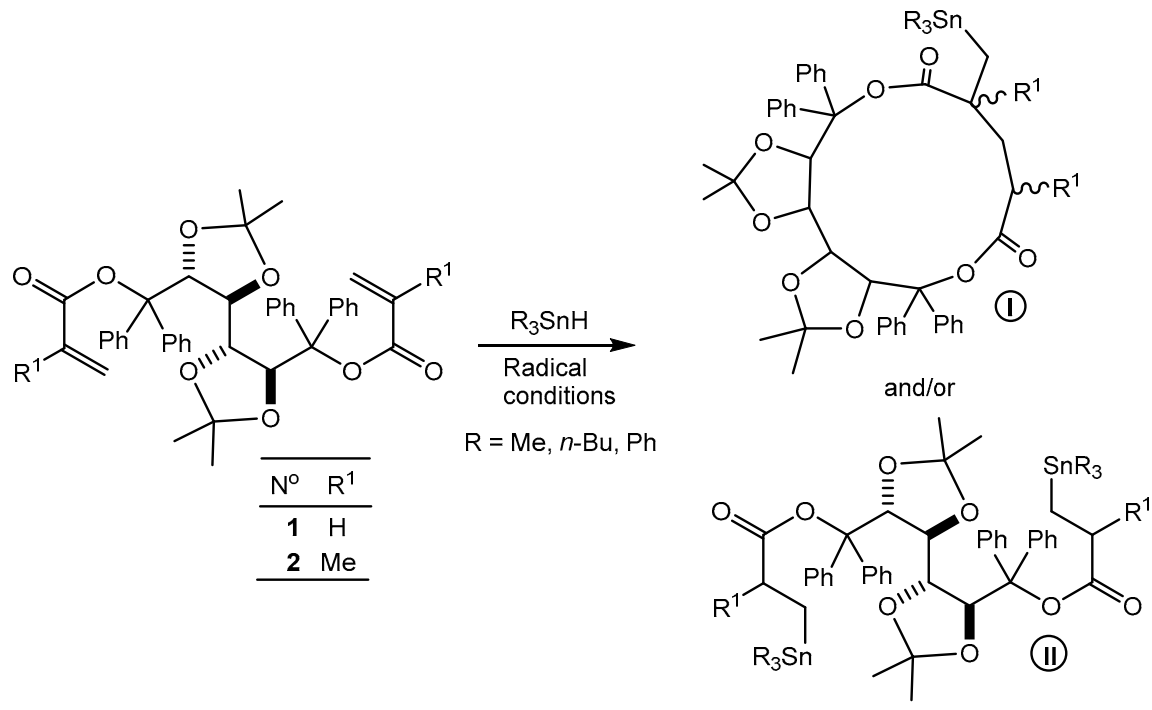

Scheme 1. Radical hydrostannation of unsaturated diesters 1 and 2.

The ${ }^{119} \mathrm{Sn}$ NMR spectrum of the mixture showed a resonance at $-3.34 \mathrm{ppm}(48 \%)$, another at 0.07 ppm (20\%), and a third signal at $5.64 \mathrm{ppm}(32 \%)$. The compound in higher proportion was separated pure by column chromatography using silica gel 60 as adsorbent. The NMR analysis together with FTIR data (see Table 1) and elemental analysis clearly showed that the major product was the macrocycle 3 (see Table 1). Thus, as seen in Table 1, the ${ }^{13} \mathrm{C}$ NMR spectrum shows the existence of two carbonyl groups (C-6 and C-10), one of them with a $3 J(C, S n)$ coupling constant (C-6). The presence of the two carbonyls was confirmed by the FTIR spectrum, which shows two peaks vco: 1760 and $1732 \mathrm{~cm}^{-1}$. The other two organotins present in the crude product could not be obtained pure. They probably are products of addition (type II, Scheme 1).

On the other hand, the addition of $\mathrm{Me}_{3} \mathrm{SnH}$ to dimethacrylate 2 led to a mixture of two organotins; the ${ }^{119} \mathrm{Sn}$ NMR spectrum showing two signals at -0.8 and $1.5 \mathrm{ppm}$. The presence in the ${ }^{13} \mathrm{C}$ NMR spectrum of four carbonyl signals at 164.88, 164.93, 175.29, and $175.39 \mathrm{ppm}$ strongly suggests that both compounds are the macrocycle products of cyclohydrostannation. Unfortunately, we were not able to obtain these compounds pure.

We then carried out the additions of $n$ - $\mathrm{Bu} 3 \mathrm{SnH}$ and $\mathrm{Ph}_{3} \mathrm{SnH}$ to diacrylate $\mathbf{1}$ and dimethacrylate 2 using the same protocol. These additions followed a different pattern. The ${ }^{119} \mathrm{Sn}$ NMR spectroscopic analysis of the crude products obtained in these additions showed, in all cases, the formation of 
mixtures of various organotins. A summary of the results obtained and some other information are included in Table 2.

Table 1. Some FTIR, ${ }^{1} \mathrm{H},{ }^{13} \mathrm{C}$, and ${ }^{119} \mathrm{Sn}$ NMR spectroscopic data of compound 3.

\begin{tabular}{|c|c|c|c|c|c|c|c|}
\hline & & $\mathrm{Me}-\mathrm{Sn}$ & C-6 & $\mathrm{C}-7$ & C-8 & C-10 & C-16 \\
\hline & $(\mathrm{ppm})\left(\mathrm{CDCl}_{3}\right)$ & $\begin{array}{l}-8.75 \\
(33.4)\end{array}$ & $\begin{array}{l}172.99 \\
(39.9)\end{array}$ & $\begin{array}{l}53.58 \\
(\mathrm{NO})\end{array}$ & $\begin{array}{l}31.73 \\
(41.0)\end{array}$ & 171.63 & $\begin{array}{c}15.33 \\
(341.4)\end{array}$ \\
\hline $2 a{ }_{3}^{2}$ & $\begin{array}{c}{ }^{\mathbf{1}} \mathbf{H} \mathbf{N M R} \\
(\mathrm{ppm})\left(\mathrm{CDCl}_{3}\right)\end{array}$ & \multicolumn{6}{|c|}{$\begin{array}{c}\left.-0.08(\mathrm{~d}, 2 \mathrm{H}) ; 0.00\left[\mathrm{~s}, 9 \mathrm{H},{ }^{2}\right)(\mathrm{Sn}, \mathrm{H})=52.4 \mathrm{~Hz}\right] \\
0.68-1.06(\mathrm{~m}, 3 \mathrm{H}) ; 1.19(\mathrm{~s}, 6 \mathrm{H}) ; 1.28(\mathrm{~s}, 6 \mathrm{H}) ; 1.87-2.35 \\
(\mathrm{~m}, 1 \mathrm{H}) ; 3.25-3.50(\mathrm{~m}, 1 \mathrm{H}) ; 4.75-4.94(\mathrm{~m}, 1 \mathrm{H}) \\
4.99-5.39(\mathrm{~m}, 1 \mathrm{H}) ; 5.89(\mathrm{~s}, 2 \mathrm{H}) ; 6.90-7.70(\mathrm{~m}, 20 \mathrm{H})\end{array}$} \\
\hline $14 a-7$ & $\begin{array}{c}{ }^{119} \text { Sn NMR } \\
(\mathrm{ppm})\left(\mathrm{CDCl}_{3}\right)\end{array}$ & \multicolumn{6}{|c|}{ 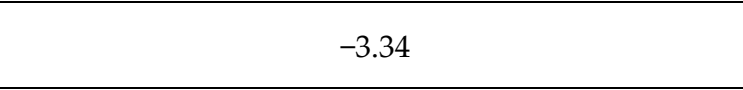 } \\
\hline $14 a$ & $\begin{array}{c}\text { FTIR } \\
\left(\mathrm{cm}^{-1}\right)(\text { Nujol })\end{array}$ & \multicolumn{6}{|c|}{$1760.05 ; 1732.63$} \\
\hline
\end{tabular}

a $\left[{ }^{\mathrm{J}}(\mathrm{C}, \mathrm{Sn})\right]$ in $\mathrm{Hz}$.

Hydrostannation of unsaturated diester $\mathbf{1}$ with $n$-Bus $\mathrm{SnH}$ afforded a mixture of two organotins (Table 2). The compound in higher proportion in the mixture is the product of diaddition $\mathbf{5}(91 \%)$, which we could not separate pure. Similarly, the addition of $\mathrm{Ph}_{3} \mathrm{SnH}$ led to just one organotin: The product of diaddition 7 , as shown in Table 2.

Table 2. Triorganotin hydride additions to unsaturated diesters $\mathbf{1}$ and $\mathbf{2}$ a.

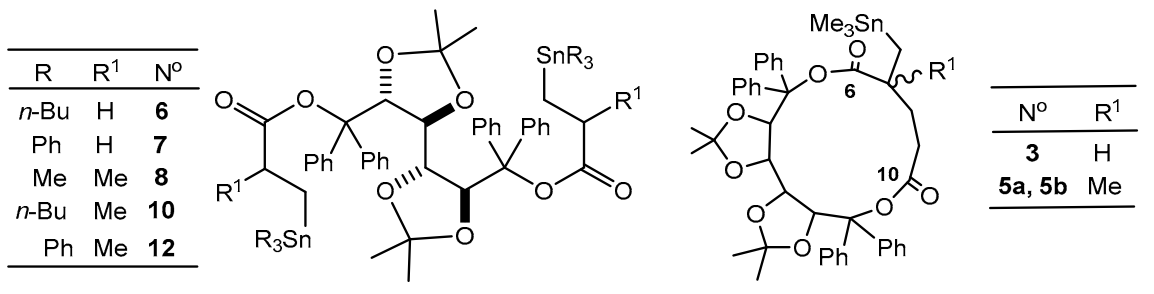

\begin{tabular}{|c|c|c|c|c|c|c|c|c|}
\hline \multirow{2}{*}{ Reaction $\mathbf{N}^{\circ}$} & \multirow{2}{*}{$\mathbf{R}$} & \multirow{2}{*}{ Ester $\mathbf{N}^{\circ}$} & \multirow{2}{*}{ Time (h) } & \multirow{2}{*}{$\begin{array}{c}\text { Adduct } \\
N^{\circ}{ }^{b}\end{array}$} & \multirow{2}{*}{$\begin{array}{c}{ }^{119} \text { Sn NMR } \\
(\text { ppm) }\end{array}$} & \multirow{2}{*}{$\begin{array}{l}\% \text { in the } \\
\text { Mixture }\end{array}$} & \multicolumn{2}{|c|}{${ }^{13} \mathrm{C}$ NMR C=O (ppm) } \\
\hline & & & & & & & C-6 & C-10 \\
\hline \multirow{3}{*}{$\mathrm{Me}$} & \multirow{3}{*}{ Me } & \multirow{3}{*}{1} & & 3 & -3.34 & 48 & \multirow{3}{*}{171.63} & \multirow{3}{*}{172.99} \\
\hline & & & & $4 a$ & -0.1 & 20 & & \\
\hline & & & & $4 b$ & 5.6 & 32 & & \\
\hline \multirow{2}{*}{2} & \multirow{2}{*}{$\mathrm{Me}$} & \multirow{2}{*}{2} & \multirow{2}{*}{16} & $5 a$ & -0.8 & 73 & \multirow{2}{*}{164.88164 .93} & \multirow{2}{*}{175.29175 .39} \\
\hline & & & & $5 b$ & 1.5 & 27 & & \\
\hline \multirow{2}{*}{$3^{d}$} & \multirow{2}{*}{$n$-Bu } & \multirow{2}{*}{1} & \multirow{2}{*}{1} & $6 a$ & -8.0 & 9 & \multirow{2}{*}{\multicolumn{2}{|c|}{$173.04(64.5)$}} \\
\hline & & & & 7 & -7.8 & 91 & & \\
\hline 4 & $\mathrm{Ph}$ & 1 & 3 & 8 & -98.2 & 100 & 172.56 & $77.2)$ \\
\hline \multirow{4}{*}{5} & \multirow{4}{*}{$n$-Bu } & \multirow{4}{*}{2} & \multirow{4}{*}{1} & \multirow{2}{*}{9} & \multirow{2}{*}{$\begin{array}{c}-12.0 \\
-99\end{array}$} & \multirow{2}{*}{60} & \multicolumn{2}{|c|}{174.84} \\
\hline & & & & & & & \multicolumn{2}{|c|}{175.17} \\
\hline & & & & \multirow{2}{*}{$10 \mathrm{~b}$} & -96 & \multirow{2}{*}{20} & \multirow{2}{*}{\multicolumn{2}{|c|}{$\begin{array}{l}175.30 \\
175.57\end{array}$}} \\
\hline & & & & & -9.6 & & & \\
\hline & & & & 11 & -104.0 & 75 & 17 & \\
\hline 6 & $\mathrm{Ph}$ & 2 & 3 & $12 a$ & -101.0 & 12.5 & 17 & \\
\hline & & & & $12 b$ & -100.8 & 12.5 & & \\
\hline
\end{tabular}

a The reactions were carried out in toluene, at $75{ }^{\circ} \mathrm{C}$, using AIBN as radical initiator except when otherwise indicated. ${ }^{\mathrm{b}}$ The compounds with numbers and letters could not be obtained pure. Compounds with just a number indicate that the compound is either pure or that the structure is clearly supported by spectroscopy. ${ }^{\mathrm{c}}$ In $\mathrm{CDCl}_{3}$; chemical shifts in ppm with respect to $\mathrm{Me}_{4} \mathrm{Sn}$. ${ }^{\mathrm{d}}$ Reaction carried out without solvent.

On the other hand, the additions of $n-\mathrm{Bu}_{3} \mathrm{SnH}$ and $\mathrm{Ph}_{3} \mathrm{SnH}$ to dimethacrylate 2, led in all cases to products of diaddition (Table 2 and Scheme 2). 

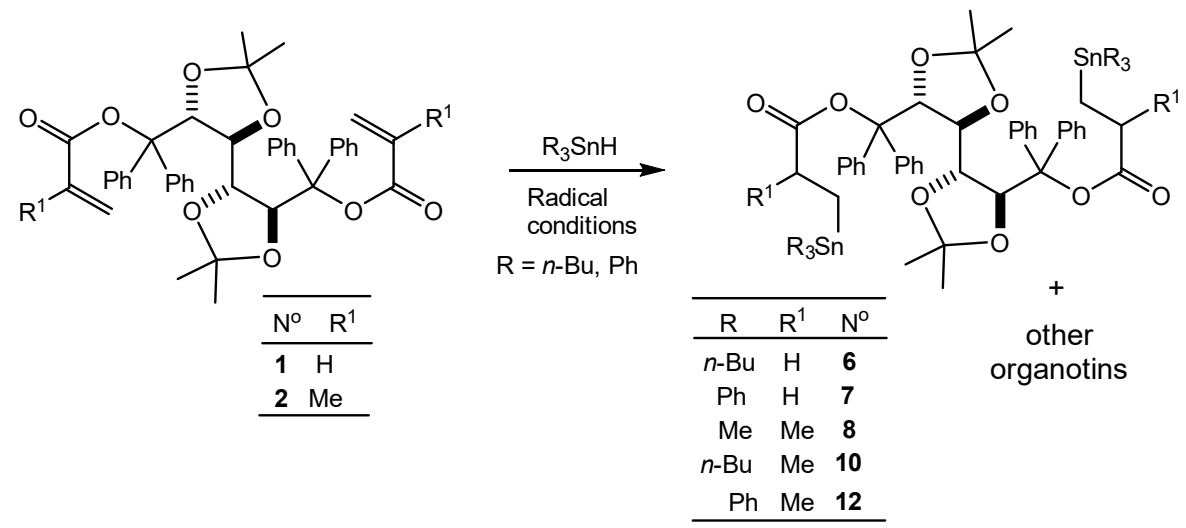

Scheme 2. Radical hydrostannation of unsaturated diesters $\mathbf{1}$ and $\mathbf{2 .}$

The presence in the ${ }^{13} \mathrm{C}$ NMR spectra of carbonyl groups around $173 \mathrm{ppm}$ (none below 170 ppm) supports that these compounds are the products of diaddition.

The results obtained so far demonstrate that the products of these radical additions depend on the nature of the substituents at the tin atom of the triorganotin hydrides. In the case of the Mes $\mathrm{SnH}$, the hydride addition would favor the operation of the cyclohydrostannation tandem radical mechanism.

Acknowledgments: CONICET and UNS of Argentina supported this work. A fellowship from CIC-PBA to V.F.T. is gratefully acknowledged.

Conflicts of Interest: The authors declare no conflict of interest.

\section{References}

1. Gerbino, D.C.; Koll, L.C.; Mandolesi, S.D.; Podestá, J.C. Stereoselective radical tandem cyclohydrostannation of optically active di-unsaturated esters of TADDOL. Organometallics 2008, 27, 660-665.

2. Gerbino, D.C.; Scoccia, J.; Koll, L.C.; Mandolesi, S.D.; Podestá, J.C. Stereoselective Synthesis and Some Properties of New Chlorodiorganotin-Substituted Macrodiolides. Organometallics 2012, 31, 662-671.

3. Scoccia, J.; Gerbino, D.C.; Podestá, J.C. Synthesis of organotin derivatives of optically active eleven-membered macrodiolides. Tetrahedron Asymmetry 2016, 27, 352-360.

(C) 2019 by the authors. Licensee MDPI, Basel, Switzerland. This article is an open access article distributed under the terms and conditions of the Creative Commons Attribution (CC BY) license (http://creativecommons.org/licenses/by/4.0/). 